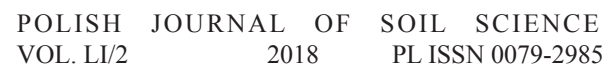

DOI: $10.17951 / \mathrm{pjss} / 2018.51 .2 .205$

TRAN BAO TRAN*, HA MANH BUI**

\title{
EFFECT OF LAND-USE CHANGES RESULTING FROM SHRIMP FARMING ON ACID SULFATE SOILS IN THE CAN GIO COASTAL WETLAND AREA (VIETNAM)
}

Abstract. Acid sulfate soils in coastal wetland areas are particularly vulnerable to land-use changes. We identified the potential impacts of land-use changes in the Can Gio coastal wetland area in Vietnam due to the reclamation of acid sulfate soils from shrimp farms. Our study applied the support of vector machine algorithm in ENVI software to observe land-use changes from 1995 to 2015, using Landsat Thematic Mapper and Operational Land Imager data. We classified the land use of the study area into four major classes including vegetation, bare land, dedicated land and aquaculture land. Our study successfully met the overall classification accuracy requirement above 95\% and kappa statistics above 0.95. Between 1995 and 2006, about 2,938.05 ha of bare land and 1,464.66 ha of vegetation (mangrove forest) were converted to aquaculture land. In contrast, between 2006 and 2015, 2,423.88 ha of aquaculture land converted back to bare land, mainly related to the abandonment of shrimp ponds due to crop failure and disease. The disturbance of acid sulfate soils through initial soil reclamation and subsequent fallowing is considered a key reason for hastening and extending soil acidification in the study area. We collected 144 topsoil samples from 17 fallowed ponds in two batches, and 142 of these were acidic: 128 samples were extremely and strongly acidic $(\mathrm{pH}<5.5), 14$ samples were moderately and slightly acid $(\mathrm{pH}$ between 5.5 and 6.5), and only two samples were neutral ( $\mathrm{pH}$ over 6.5).

Keywords: land use, acid sulfate soils, shrimp farming, supervised classification, soil reclamation

* Institute for Environment and Resources, Vietnam National University of Ho Chi Minh city, Vietnam and Graduate school of Environmental Science, Hokkaido University, Sapporo, Japan.

** Department of Environmental Sciences, Saigon University, Vietnam; corresponding author: manhhakg@sgu.edu.vn 


\section{INTRODUCTION}

Naturally occurring acid sulfate soils (ASSs) contain sulfides (e.g., pyrite) and sulfuric acid. They can also generate acid through the oxidation of sulfides (Shi et al. 2014). The worldwide distribution of ASSs is estimated to be over $500,000 \mathrm{~km}^{2}$ and occurs across climatic regions ranging from temperate to tropical zones (Fanning et al. 2017, Ruprecht et al. 2018). Most ASSs are located in coastal wetland areas (Högfors-Rönnholm et al. 2018), which are also often developed areas with high population densities due to their good climatic conditions. This makes them potentially valuable for the development of aquaculture (Widyatmanti and Sammut 2017). The rapid development of shrimp farming in coastal plains has coincided with the loss of natural mangrove forests, wetlands and sediments (Mahmood and Saikat 1995, Perryman et al. 2017).

This rapid expansion of shrimp farm has resulted in the over-exploitation of coastal sediments and ASS disturbances through drainage. This has, in turn, increased the exposure of pyrite to oxygen, thus, generating excess of acid and leading to a soil $\mathrm{pH}$ of less than 3.5. As the concentration of sulphate has increased, so has the presence of secondary iron minerals (jarosite, hematite, goethite, etc.). Once shrimp farms become acidified, they are often abandoned, leading to increased pollution pressure on both land and water resources (Sammut et al. 1997). Currently, the production of shrimp on ASS is considered unsustainable (Mahmood and Saikat 1995) and soil acidification caused by reclaimed ASS for aquaculture has become a worldwide concern in coastal wetlands in recent years. Because of this, detecting and evaluating the potential presence of acidic soil is necessary work to limit the over-exploitation of ASS and prevent formation of new acidified areas. Newly acidified areas can increase the risk of pollution as soil is reclaimed back into the environment.

The traditional method to monitor the acidic state of soil has been the analysis of soil samples, but this method has not shown the linkage between land-use changes and alteration of soil properties at large scales. However, the combination of remote sensing and traditional methods promises to clarify the process of land-use changes caused by human activities in particular areas.

Remote sensing is a cost-effective and time-saving tool for detecting land-use changes. Many researchers around the world use a support vector machine (SVM), which is a supervised classification method to analyse images and detect land-use changes (Karan and Samadder 2016, Martins et al. 2016, Ustuner et al. 2015). Their results verify that the SVM algorithm has higher accuracy than the maximum likelihood classifier algorithm in land-use mapping. Therefore, the SVM algorithm has been suggested as an optimal classifier for extraction of data from land-use maps due to its higher accuracy (Karan and Samadder 2016, Taati et al. 2014). 
In Vietnam, the massive and unplanned development of shrimp farms has created a problem for sustainable development. Large farming areas have been abandoned after only a few crops due to disease, crop failure, devaluation, etc. (Nho et al. 2018, Phuoc and Massel 2006, Thuong and Thach 2017). Thao et al. (2012) indicated that, in 2008, fallowed areas of shrimp ponds comprised 28,821 ha in North and North Central Vietnam; 13,907 ha in Central Vietnam, and 67,591 ha in South Vietnam, indicating a total of 110,320 ha of fallowed land for the entire country of Vietnam.

We sought to monitor the land-use changes due to reclamation of ASS for shrimp farm in the Can Gio area. Rapid development of aquaculture in Can Gio has led to environmental problems such as mangrove forest degradation (Son et al. 2016), soil acidification (Lieu 2002), and surface water pollution from waste water generated by soil raising activities (Anh et al. 2010, Trai et al. 2006, Tuan et al. 2005). We analysed remotely sensed data to distinguish the extent of changes that have occurred in the Can Gio coastal wetland area over a 20-year time period (1995 to 2015) and assessed the effects of ASS reclamation for shrimp farm on soil properties.

\section{MATERIALS AND METHODS}

\section{Study area}

Can Gio is located about $50 \mathrm{~km}$ southeast of Ho Chi Minh City between latitude of $10^{\circ} 22^{\prime} 14^{\prime \prime} \mathrm{N}$ and $10^{\circ} 40^{\prime} 00^{\prime} \mathrm{N}$, and between longitude of $106^{\circ} 46^{\prime} 12^{\prime \prime} \mathrm{E}$ and $107^{\circ} 00^{\prime} 50^{\prime} \mathrm{E}$ (Fig. 1) and has a total area of $\pm 70,421.58$ ha (including 20,922.66 ha of waterways). Together with Can Thanh Township, six communes - including Can Thanh Township, Binh Khanh, An Thoi Dong, Tam Thon Hiep, Long Hoa and Thanh An - form the human communities of Can Gio with a population of $\pm 71,000$ people (Nam et al. 2014, Thuong and Thach 2017).

The topography of Can Gio is generally flat and low-lying with an average elevation of 0.5 to $2 \mathrm{~m}$. It is mostly composed of clayey/silty soils that contain peat. The parent materials of these soils are Quaternary pyritic deposits of the late-present Holocene age with marine, alluvial-marine, or swampy-marine origins (Hai et al. 1989), and is dominated by saline ASS (Thionic-Salic Fluvisols) in 43,945 ha of the Can Gio (Lieu 2002).

The tropical climate of Can Gio is typically monsoonal with two distinctive seasons (Kuenzer and Tuan 2013, McDonough et al. 2014, Son et al. 2016). The dry season is from November to May and the rainy season is from June to October. The average daily temperature is 25.7 to $28.5^{\circ} \mathrm{C}$ and the amount of sunshine varies between five and nine hours per day. Solar radiation is very high at $\pm 140 \mathrm{kcal} \mathrm{cm}^{-2}$ year ${ }^{-1}$, evaporation is between 1,000 and $1,200 \mathrm{~mm} / \mathrm{year}^{-1}$, and 


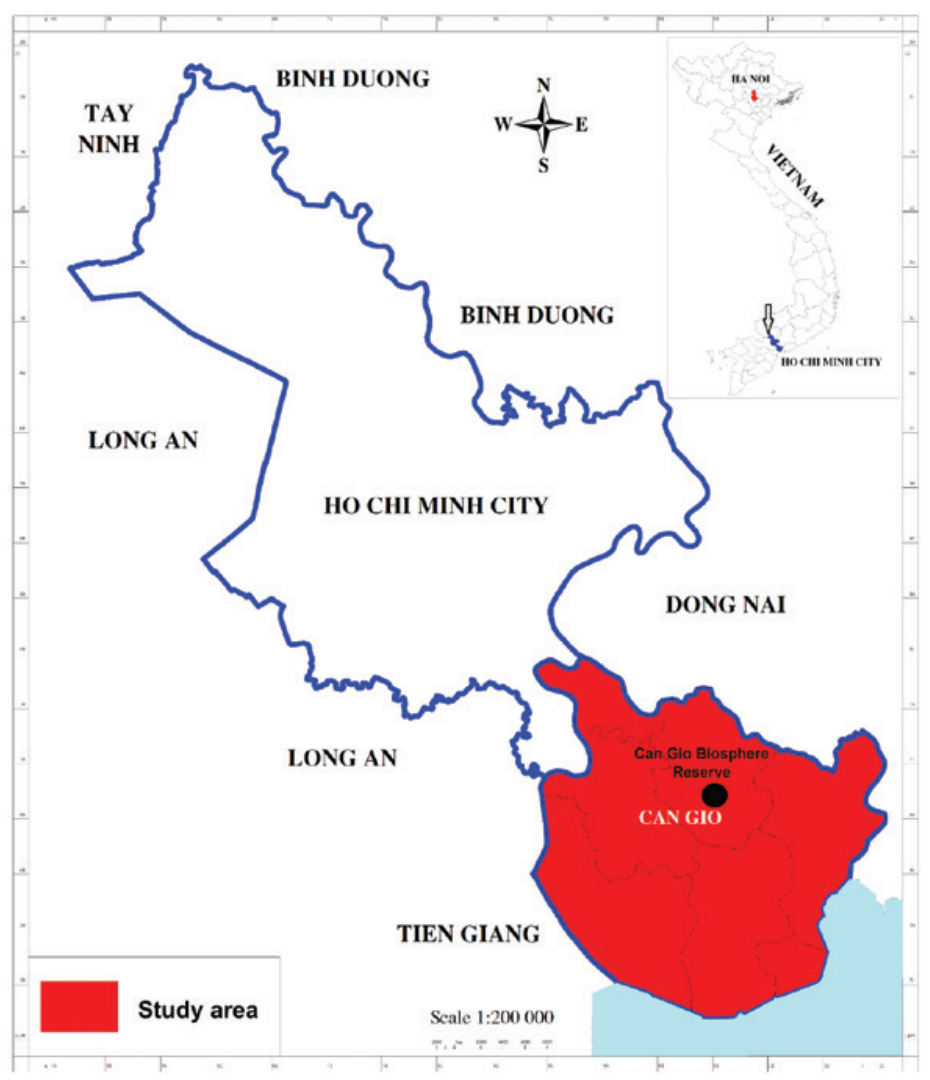

Fig. 1. Geographic location of the study area

air humidity is between 74 and $83 \%$. These natural conditions ensure that soil oxidation occurs rapidly and with high intensity.

In Can Gio, the main land-use types include mangrove forest $( \pm 33,050.39$ ha, $-46.93 \%$ ) - which is strictly protected by the board of the Can Gio Mangrove Biosphere Reserve, land used for residents, agriculture, aquaculture and dedicated purposes to human use, i.e. settlements, roads or salt pans $( \pm 37,353.26$ ha, $-53.04 \%$ ), and unused land ( $\pm 17.93 \mathrm{ha},-0.03 \%)$ (Nho et al. 2018).

The initial soil reclamation through drainage or fallow Thionic Fluvisols would hasten soil acidification, and adversely affect habitats in Can Gio by threatening the ecological values of this study area which is declared as a Biosphere Reserve by UNESCO since 2000 (Nam et al. 2014, Son et al. 2016).

\section{Data preparation}

The data used in this research included Landsat 5 Thematic Mapper (TM) data and Landsat 8 Operational Land Imager (OLI) data. Ground truth data were collected using a Geographical Positioning System device (Garmin eTrex ${ }^{\circledR} 20$ ) 
in March 2015 to use as reference data for image classification and overall accuracy assessment of the classification results. Satellite data for three years (1995, 2006, and 2015) consisted of multi-spectral data acquired by Landsat satellite for the months of February and March, provided by the US Geological Survey (USGS) Earth Explorer.

We conducted two soil sampling batches, in March 2015 and again in February 2017 , to investigate soil properties after being reclaimed for shrimp farming and subsequently abandoned. In the first batch, 90 topsoil samples were randomly taken from 11 fallow farms (ca. $6.1 \mathrm{ha}$ ) three months to two years after being abandoned. In the second batch, 54 topsoil samples were randomly taken from six fallowed farming (ca. 1.44 ha) two months to three years after being abandoned. Although many fallowed farms had not been reclaimed, some of the fallowed farms were filled with sulfidic materials from adjacent canals. These farms subsequently became bare land.

Of the 144 total topsoil samples from the 17 sites and two batches, 114 samples were taken from inside dry farms and 30 samples were taken from the edges of wet farms. Of the 17 sites, two sites were repeated to check the progress of soil acidification over time (CG1-A6 $\cong \mathrm{CG} 2-\mathrm{A} 4$; CG1-A9 $\cong \mathrm{CG} 2-\mathrm{A} 3)$. The soil type of the samples were Thionic Fluvisols at depths of zero to $10 \mathrm{~cm}$ (Fig. 2). The $\mathrm{pH}$ values of the soil samples were measured in natural conditions (the ratio of soil to distilled water was one to five) by using a hand-held, field model $\mathrm{pH}$ probe (Takemura Electric Works, Tokyo). The locations of soil samples were transformed to the Universal Transverse Mercator (WGS84) projection in zone $48 \mathrm{~N}$ so that they would be the same as the Landsat data projections.

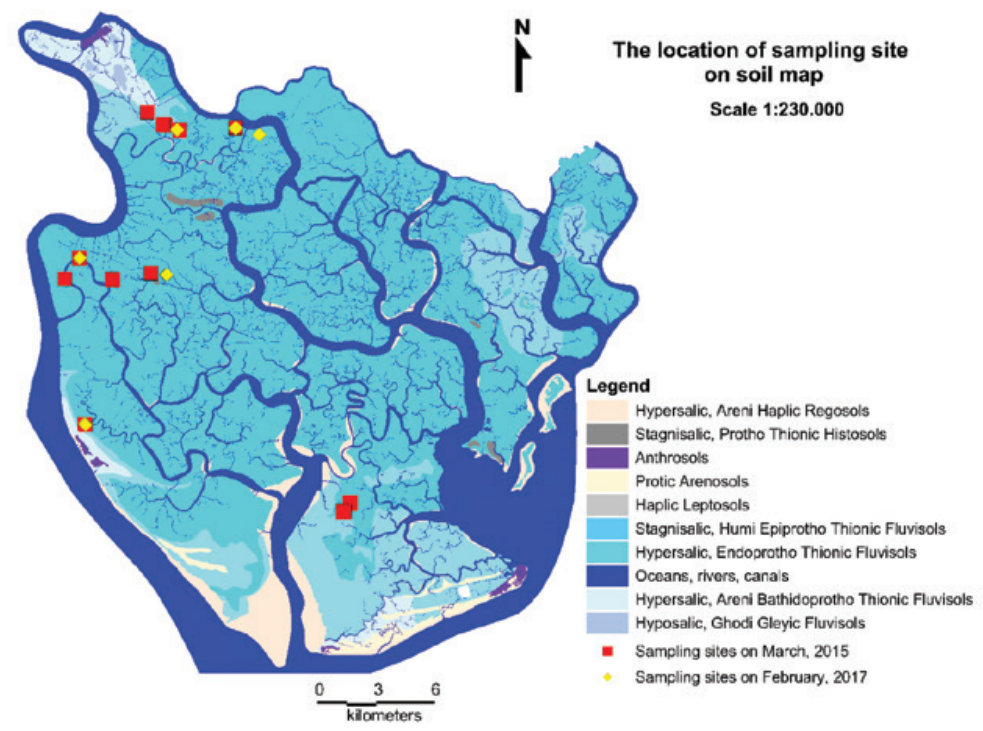

Fig. 2. The location of sampling sites on a soil map of Can Gio 


\section{Pre-processing and classification}

Data were pre-processed in ENVI 4.5 for geo-referencing, mosaicking and sub-setting of the region of interest. All satellite data were assigned per-pixel signatures into four classes. These delineated classes were vegetation, including mangrove forest, rice fields and fruit trees; bare land that was reclaimed from cut-down mangrove forest in the past for agricultural purposes but fallowed thereafter; aquaculture land, including shrimp farming; and land dedicated to human use with the presence of settlements, roads and salt pans. We then used the SVM algorithm for supervised classification. Finally, the classified images were cut to eliminate river systems using the district and river boundaries of a topography map at scale of 1:5,000.

\section{Accuracy assessment of the classification method}

To determine the quality of information derived from the satellite images, we evaluated the classification accuracy of the 1995, 2006 and 2015 images. We assessed our data using a stratified random method proportionate to $50 \%$ of the sample size to confirm the different land-use classes of the study area.

\section{Detection of land-use changes}

We used a post-classification technique called change detection analysis to detect the location, nature, and area sizes of land-use changes. A change detection statistic was determined for the stages from 1995 to 2006 and again from 2006 to 2015 to identify the conversions from one distinct land-use type to another land-use type.

\section{RESULTS}

The overall classification accuracies of our 1995, 2006 and 2015 images were $96.87 \%, 98.18 \%$ and $98.72 \%$, respectively. Our overall kappa statistics for the 1995, 2006 and 2015 images were $0.9609,0.9773$ and 0.9840 , respectively. These results show that we successfully met both the required overall classification accuracy above $95 \%$ and that our kappa statistics were above 0.95 . The results of our change detection for 1995, 2006 and 2015 are summarised in Figure 3 and Table 1. 

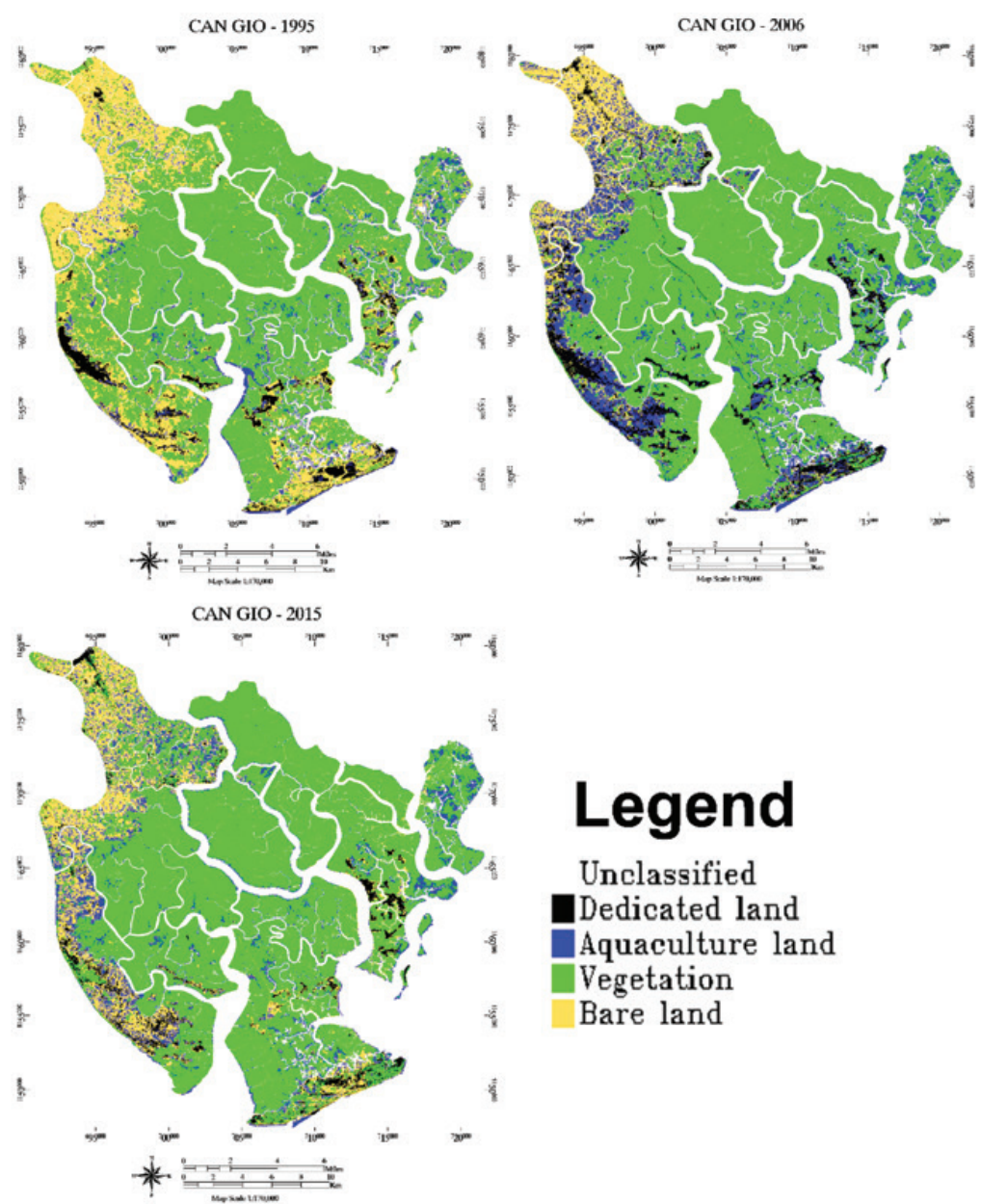

Unclassified

Dedicated land

Aquaculture land

Vegetation

Bare land

Fig. 3. Classified maps of Can Gio area (1995, 2006 and 2015)

Table 1. Land-use change overtime (area in hectares)

\begin{tabular}{cccccc}
\hline Land-use classes & \multirow{2}{*}{1995} & 2006 & 2015 & $\begin{array}{c}\text { Change from1995 } \\
\text { to 2006 }\end{array}$ & $\begin{array}{c}\text { Change from } \\
\text { 2006 to 2015 }\end{array}$ \\
\hline Vegetation & $32,693.13$ & $34,281.9$ & $36,334.89$ & $1,588.77$ & $2,052.99$ \\
Dedicated land & $1,979.46$ & $3,878.91$ & $1,964.25$ & $1,899.45$ & $-1,914.66$ \\
Bare land & $12,020.4$ & $5,132.25$ & $7,258.14$ & $-6,888.15$ & $2,125.89$ \\
Aquaculture land & $2,805.93$ & $6,205.86$ & $3,941.64$ & $3,399.93$ & $-2,264.22$ \\
Total & $49,498.92$ & $49,498.92$ & $49,498.92$ & 0 & 0 \\
\hline
\end{tabular}

As seen in Table 1, the amount of bare land decreased by $6,888.15$ ha between 1995 and 2006, and this corresponds to the increase in vegetation (1,588.77 ha), dedicated land (1,899.45 ha), and aquaculture land (3,399.93 ha). 
During this time, 2,938.05 ha of bare land and 1,464.66 ha of vegetation (mangrove forest) were converted to aquaculture land (Table 2).

In contrast, between 2006 and 2015, vegetation increased by 2,052.99 ha and bare land increased by $2,125.89$ ha, which corresponds to a decrease of dedicated land by $1,914.66$ ha and aquaculture land by $2,264.22$ ha. In particular, $2,423.88$ ha of aquaculture land converted to bare land and this relates to the abandonment of shrimp farm due to crop failure and disease. The detail of conversions between land-use types and their changes of equivalent areas, between 1995 and 2006 and between 2006 and 2015 are shown in Table 2 and Table 3, respectively.

Table 2. The detailed change of land-use types between 1995 and 2006 (area in hectares)

\begin{tabular}{|c|c|c|c|c|c|c|}
\hline \multirow{2}{*}{\multicolumn{2}{|c|}{ Land-use classes }} & \multicolumn{5}{|c|}{1995} \\
\hline & & Vegetation & $\begin{array}{c}\text { Dedicated } \\
\text { land }\end{array}$ & Bare land & $\begin{array}{c}\text { Aquaculture } \\
\text { land }\end{array}$ & Class Total \\
\hline \multirow{7}{*}{$\begin{array}{l}2 \\
0 \\
0 \\
6\end{array}$} & Vegetation & $29,341.26$ & 114.75 & $3,853.71$ & 972.18 & $34,281.9$ \\
\hline & Dedicated land & 642.6 & $1,474.83$ & $1,668.87$ & 92.61 & $3,878.91$ \\
\hline & Bare land & $1,244.61$ & 160.02 & $3,559.77$ & 167.85 & $5,132.25$ \\
\hline & Aquaculture land & $1,464.66$ & 229.86 & $2,938.05$ & $1,573.29$ & $6,205.86$ \\
\hline & Class total & $32,693.13$ & $1,979.46$ & $12,020.4$ & $2,805.93$ & 0 \\
\hline & Class changes & $3,351.87$ & 504.63 & $8,460.63$ & $1,232.64$ & 0 \\
\hline & Image difference & $1,588.77$ & $1,899.45$ & $-6,888.15$ & $3,399.93$ & 0 \\
\hline
\end{tabular}

Table 3. The detailed change of land-use types between 2006 and 2015 (area in hectares)

\begin{tabular}{|c|c|c|c|c|c|c|}
\hline \multirow{2}{*}{\multicolumn{2}{|c|}{ Land-use classes }} & \multicolumn{5}{|c|}{2006} \\
\hline & & Vegetation & $\begin{array}{l}\text { Dedicated } \\
\text { land }\end{array}$ & Bare land & $\begin{array}{l}\text { Aquaculture } \\
\text { land }\end{array}$ & Class Total \\
\hline \multirow{7}{*}{$\begin{array}{l}2 \\
0 \\
1 \\
5\end{array}$} & Vegetation & $33,147.63$ & 707.58 & $1,480.59$ & 999.09 & $36,334.89$ \\
\hline & Dedicated land & 58.95 & $1,410.84$ & 224.55 & 269.91 & $1,964.25$ \\
\hline & Bare land & 510.66 & $1,503.54$ & $2,820.06$ & $2,423.88$ & $7,258.14$ \\
\hline & Aquaculture land & 564.66 & 256.95 & 607.05 & $2,512.98$ & $3,941.64$ \\
\hline & Class total & $3,4281.9$ & $3,878.91$ & $5,132.25$ & $6,205.86$ & 0 \\
\hline & Class changes & $1,134.27$ & $2,468.07$ & $2,312.19$ & $3,692.88$ & 0 \\
\hline & Image difference & $2,052.99$ & $-1,914.66$ & $2,125.89$ & $-2,264.22$ & 0 \\
\hline
\end{tabular}

Since most of the soils in Can Gio are ASSs, the mutual conversion processes of reclaiming bare land to become aquaculture land and then allowing them to go fallow again will directly alter soil properties. Potential ASS layers can become actual ASS layers through digging and turning over the soil. We collected 144 topsoil samples in two batches to assess the impact of reclaiming ASS for aquaculture 
(shrimp farm) on changes in soil properties. We especially considered the acidic state of the soil by measuring $\mathrm{pH}$ values. Our analysis showed that 128 sampling sites were strongly acidic ( $\mathrm{pH}<5.5), 14$ samples were moderately to slightly acidic $(5.5 \leq \mathrm{pH} \leq 6.5)$, and two samples were $\mathrm{pH}$ neutral (Fig. 4). The largest number of strong acidic soil samples came from the edges of farms (30 samples) and fallowed farms that had oxidised within the last two months to three years (98 samples). The moderately acidic to neutral samples were mainly scattered in fallowed farms that had undergone a liming regime during soil reclamation and before raising. We conclude that irregular liming regimes may have had an impact on the change of soil acidity within the same farm.

We repeated sampling at two of the 17 investigated sites to check the progress of soil acidity at these fallowed farms over time. Table 4 shows the slight increase in soil acidity over the two years. It is noted that soil acidity could have remained stable for many years under natural condition if left untreated by liming.

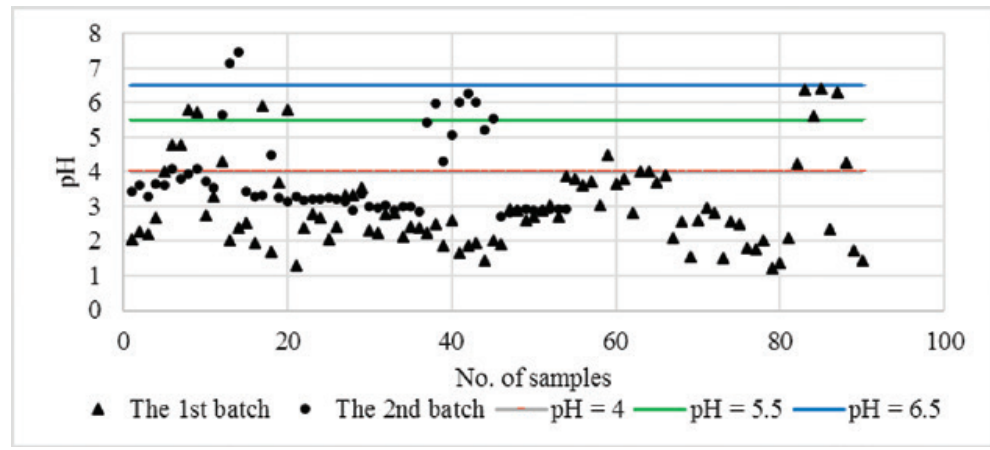

Fig. 4. pH values of topsoil samples in two sampling batches

Table 4. $\mathrm{pH}$ values indicating soil acidity at two shrimp farms, repeated over a two-year period

\begin{tabular}{ccccc}
\hline \multirow{2}{*}{ No. of samples } & \multicolumn{2}{c}{ CG1-A9 $\cong$ CG2-A3 } & \multicolumn{2}{c}{ CG1-A6 $\cong$ CG2-A4 } \\
& Mar-15 & Feb-17 & Mar-15 & Feb-17 \\
\hline 1 & 2.10 & 3.24 & 1.88 & 2.90 \\
2 & 2.55 & 3.13 & 2.61 & 3.36 \\
3 & 1.55 & 3.27 & 1.64 & 2.99 \\
4 & 2.60 & 3.19 & 1.86 & 2.97 \\
5 & 2.96 & 3.22 & 1.95 & 3.04 \\
6 & 2.81 & 3.20 & 1.42 & 2.88 \\
7 & 1.49 & 3.24 & 2.03 & 3.00 \\
8 & 2.56 & 3.20 & 1.90 & 2.99 \\
9 & 2.50 & 3.15 & 2.91 & 2.86 \\
\hline
\end{tabular}




\section{DISCUSSION}

The soil $\mathrm{pH}_{1: 5 \mathrm{w}}$ measurements of the fallowed farms proved that the topsoil was an actual ASS layer, while the research by Lieu (2002) showed that the topsoil layer of bare land had a soil $\mathrm{pH}$ of approximately 3.5. This demonstrates that the topsoil layer investigated in this study is a potential ASS layer that was disturbed and exposed to air through soil reclamation for the shrimp farms, leading to oxidation and turning the potential ASS into actual ASS layers.

It should be noted that, in the Can Gio area, soil acidification can happen repeatedly during soil reclamation for land-use purposes such as cutting down mangroves for rice fields or converting uncultivated rice fields to shrimp farms and fallowing them thereafter. This inefficient way of using the land can make ASSs degrade more rapidly and can contribute to the potential risk of future contamination.

\section{CONCLUSIONS}

The results from the study have led to the following conclusions:

1. There was a continuous reclamation of bare land for shrimp farms between 1995 and 2006, and a conversion from shrimp farms back to bare land (fallowed farms) between 2006 and 2015.

2. Some shrimp farms became fallowed farms after only a few crop cycles due to economic losses caused by disease, poor crops, devaluation, etc.

3. Most soil samples $(89 \%)$ collected from fallowed farms in Can Gio were strongly acidic (128/144), $10 \%$ were moderately to slightly acidic with a $\mathrm{pH}$ between 5.5 and $6.5(14 / 144)$, and only $1 \%$ were in a neutral condition $(2 / 144)$.

4. Natural recovery from soil acidification in the farming will require many years if left untreated by liming.

It is essential to tightly control the coastal wetland resources of Can Gio to prevent enlargement of ASS layers in the future.

\section{ACKNOWLEDGMENTS}

The authors are thankful to the Hokkaido University and Vietnam National University - Ho Chi Minh City for their financial and technical supports. We also owe special thanks to Professor Kazuhiro Toyoda from the Hokkaido University and Professor Phuoc Van Nguyen from Vietnam National University - Ho Chi Minh City for their valuable suggestions at various stages of our research. 


\section{REFERENCES}

[1] Anh, P.T., Kroeze, C., Bush, S.R., Mol, A.P.J., 2010. Water pollution by intensive brackish shrimp farming in south-east Vietnam: Causes and options for control. Agricultural Water Management, 97(6): 872-882, DOI: 10.1016/j.agwat.2010.01.018.

[2] Fanning, D.S., Rabenhorst, M.C., Fitzpatrick, R.W., 2017. Historical developments in the understanding of acid sulfate soils. Geoderma, 308: 191-206, DOI: 10.1016/j.geoderma.2017.07.006.

[3] Hai, H.Q., My, B.P., Co, M.C., 1989. Quaternary strata in Ho Chi Minh City and the Eastern Region of South Vietnam. Geology and Mineral Materials, 210-223.

[4] Högfors-Rönnholm, E., Christel, S., Dalhem, K., Lillhonga, T., Engblom, S., Österholm, P., Dopson, M., 2018. Chemical and microbiological evaluation of novel chemical treatment methods for acid sulfate soils. Science of The Total Environment, 625: 39-49, DOI: 10.1016/j.scitotenv.2017.12.287.

[5] Karan, S.K., Samadder, S.R., 2016. Accuracy of land use change detection using support vector machine and maximum likelihood techniques for open-cast coal mining areas. Environmental Monitoring and Assessment, 188(8): 1-13, DOI: 10.1007/s10661-016-5494-X.

[6] Kuenzer, C., Tuan, V.Q., 2013. Assessing the ecosystem services value of Can Gio Mangrove Biosphere Reserve: Combining earth-observation and household-survey-based analyses. Applied Geography, 45: 167-184, DOI: 10.1016/j.apgeog.2013.08.012.

[7] Lieu, P., 2002. Coastal saline acid sulphate soils with aquaculture and mangroves: A case study in Hochiminh city environs. In: $17^{\text {th }}$ World Congress of Soil Science, Bangkok, Thailand, pp. 536-546.

[8] Mahmood, N., Saikat, S.Q., 1995. On acid sulfate soils of the coastal aquaculture ponds of Bangladesh. Pakistan Journal of Marine Sciences, 4(1): 39-43.

[9] Martins, S., Bernardo, N., Ogashawara, I., Alcantara, E., 2016. Support vector machine algorithm optimal parameterization for change detection mapping in Funil Hydroelectric Reservoir (Rio de Janeiro State, Brazil). Modeling Earth Systems and Environment, 2(3): 1-10, DOI: 10.1007/s40808-016-0190-y.

[10] McDonough, S., Gallardo, W., Berg, H., Trai, N.V., Yen, N.Q., 2014. Wetland ecosystem service values and shrimp aquaculture relationships in Can Gio, Vietnam. Ecological Indicators, 46: 201-213, DOI: 10.1016/j.ecolind.2014.06.012.

[11] Nam, V.N., Sinh, L.V., Miyagi, T., Baba, S., Chan, H.T., 2014. An overview of Can Gio District and Mangrove Biosphere Reserve. Studies in Can Gio Mangrove Biosphere Reserve, Ho Chi Minh City, Vietnam Mangrove Ecosystems Technical Reports, 6: 1-7.

[12] Nho, T.N., Emilie, S., Trang, N.T.T., Frank, D., Cyril, M., 2018. Trace metals partitioning between particulate and dissolved phases along a tropical mangrove estuary (Can Gio, Vietnam). Chemosphere, 196: 311-322, DOI: 10.1016/j.chemosphere.2017.12.189.

[13] Perryman, S.E., Lapong, I., Mustafa, A., Sabang, R., Rimmer, M.A., 2017. Potential of metal contamination to affect the food safety of seaweed (Caulerpa spp.) cultured in coastal ponds in Sulawesi, Indonesia. Aquaculture Reports, 5: 27-33, DOI: 10.1016/j.aqrep.2016.12.002.

[14] Phuoc, H.L.V., Massel, S.R., 2006. Experiments on wave motion and suspended sediment concentration at Nang Hai, Can Gio mangrove forest, Southern Vietnam. Oceanologia, 48(1): 23-40.

[15] Ruprecht, J.E., Glamore, W.C., Rayner, D.S., 2018. Estuarine dynamics and acid sulfate soil discharge: Quantifying a conceptual model. Ecological Engineering, 110: 172-184, DOI: 10.1016/j.ecoleng.2017.11.017.

[16] Sammut, J., White, I., Melville, M.D., 1997. Acidification of an estuarine tributary in eastern Australia due to drainage of acid sulfate soils. Oceanographic Literature Review, 5(44): 445-459.

[17] Shi, X.Z., Aspandiar, M., Oldmeadow, D., 2014. Reflectance spectral characterization of acid sulphate soil in South Yunderup, Western Australia. International Journal of Remote Sensing, 35(10): 3537-3555, DOI: 10.1080/01431161.2014.907938. 
[18] Son, N.T., Thanh, B.X., Da, C.T., 2016. Monitoring mangrove forest changes from multi-temporal Landsat data in Can Gio Biosphere Reserve, Vietnam. Wetlands, 36(3): 565-576, DOI: 10.1007/s13157-016-0767-2.

[19] Taati, A., Sarmadian, F., Mousavi, A., Pour, C.T.H., Shahir, A.H.E., 2014. Land use classification using support vector machine and maximum likelihood algorithms by Landsat 5 TM images. Walailak Journal of Science and Technology (WJST), 12(8): 681-687, DOI: $10.14456 /$ WJST.2015.33.

[20] Thao, V.N., Cu, D.N., Thanh, X.N., 2012. Maping and detecting fallowed area of cultivated tiger shrimp ponds of coastal provinces by using remote sensing data (in Vietnamese). Journal of Marine Science and Technology, 12(3): 34-45.

[21] Thuong, V.T., Thach, H.N., 2017. Assessing the impact of climate change and sea level rise on shrimp farming in Can Gio district, Ho Chi Minh City. Journal of Science of Ho Chi Minh University of Education, 14(9): 187-199.

[22] Trai, V.N., Salim, M., Kenneth, Z., 2006. Water pollution concerns in shrimp farming in Vietnam: A case study of Can Gio, Ho Chi Minh City. The International Journal of Environmental, Cultural, Economic and Social Sustainability, 3(2): 129-138, DOI: 10.18848/1832-2077/ $\mathrm{CGP} / \mathrm{v} 03 \mathrm{i} 02 / 54339$.

[23] Tuan, X.L., Munekage, Y., Kato, S., 2005. Antibiotic resistance in bacteria from shrimp farming in mangrove areas. Science of The Total Environment, 349(1): 95-105, DOI: 10.1016/j. scitotenv.2005.01.006.

[24] Ustuner, M., Sanli, F.B., Dixon, B., 2015. Application of support vector machines for landuse classification using high-resolution Rapid Eye images: A sensitivity analysis. European Journal of Remote Sensing, 48(1): 403-422, DOI: 10.5721/EuJRS20154823.

[25] Widyatmanti, W., Sammut, J., 2017. Hydro-geomorphic controls on the development and distribution of acid sulfate soils in Central Java, Indonesia. Geoderma, 308: 321-332, DOI: 10.1016/j.geoderma.2017.08.024. 